Przegląd Badań Edukacyjnych Educational Studies Review

ISSN 1895-4308

nr 30 (1/2020), s. 211-230

METAANALIZY

BADAŃ

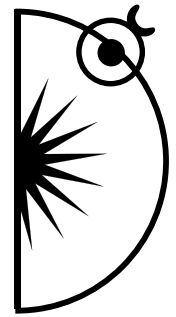

Izabella Kust

ORCID: http://orcid.org/0000-0003-2153-2404

Warsaw Management University, Warsaw, Poland; e-mail: wiziza@op.pl

\title{
Vocational Education and Training in the Light of the Reforms of Polish Education System in the Years 1999-2017'
}

http://dx.doi.org/10.12775/PBE.2020.012

\begin{abstract}
Vocational education and training (VET) is subject to permanent transformation, which results from the need to adapt it to the labour market and implement new technologies, as well as from globalisation, membership in the European Union, and modernisation of education systems. The aim of this article is to present changes in vocational education and training in Poland in the years 1999-2017 and their consequences. The results included, among other things, phasing out vocational education and training in favour of general education, which clearly deprived the labour market of qualified specialists. Bringing back the prestige of vocational education is currently one of the priorities of the state's education policy. This attempt requires the involvement of various stakeholders, not only school community and educational circles, but also employers. The need to build a positive image of vocational education and training in society, both at the level of secondary and sectoral vocational schools offering training in blue collar jobs, which are in high demand in the labour market, currently poses a social challenge.
\end{abstract}

Key words: vocational education and training, education system reform, effectiveness of education and training, qualifications, employers.

${ }^{1}$ The topic of this article was discussed in the form of Polish contribution to the project entitled „Reducing Early School Leaving in the EU” implemented under the 7th Framework Programme of the European Union in 2013-2018 by the Faculty of Pedagogy at the University of Warsaw. 


\section{Introduction}

Social, political and economic changes observed after 1989 in Poland significantly affected vocational education and training in the country. The reorganisation of this education sector resulted from dynamic processes that took place in the labour market, in enterprises, and also stemmed from the situation in the country related to Poland's accession to the European Union on 1 May 2004.

Changing environment, observation of solutions adopted by education systems abroad and experience gained in domestic market over many years caused the state of permanent change in vocational education and training in Poland.

At present yet another reform of Vocational Education and Training (VET) sector is being implemented, so it is worthwhile to make a synthetic analysis of the changes taking place in these schools.

\section{Structural changes resulting from the reforms of the education system in the years 1999-2017}

Reforms that were adopted in VET sector not always favoured the development of this type of education, which is exemplified by the reform of the education system of 1999 .

"The first act resulting in profound changes in the system (and structure) of education, both at the primary and secondary (upper secondary) school level was adopted by the Sejm and Senate and signed by Aleksander Kwaśniewski, the President of the Republic of Poland, on 25 July 1998 (OJ 1998, item 759). The act entered into force on 1 January 1999 and marked the start of the first stage of the reform of the education system in Poland and phasing out of secondary vocational education" (Kabaj, 2012, p.29).

At the time, the fear of too early student profiling led to a strong focus on general education, while at the same time students' entry into decidedly profiled education was delayed. The structure introduced with the reform included a sixyear primary school, a three-year lower secondary school (gimnazjum), threeyear general upper secondary schools (liceum ogólnoksztatcace), three- or fouryear technical upper secondary schools (technikum zawodowe) and two-year vocational schools (szkoła zawodowa). In the years 2002-2014, also three-year specialised upper secondary schools (liceum profilowane) operated. 
As far as vocational schools are concerned, the reform was a continuation of the process of their gradual phasing out that started in 1990, and, as a consequence, closing down of such schools. This situation was influenced by a number of factors, including, inter alia: the restructuring or closedown of enterprises running company schools and "(...) unemployment of graduates of schools operating in this sector. It results mainly from poor adaptation of specialisations and volume of vocational education these schools offered to the dynamically changing needs of the labour market" (Kwiatkowski, 1993; 2002). These factors led to a strong focus on general education, which resulted in the lack of interest on the part of young people in receiving education at vocational and technical schools. Marginalisation of vocational education and training led to the closing down of the majority of basic vocational schools, and vocational education and training was transferred to the level of post-secondary education.

"The authors of the education system reform in Poland adopted two strategic goals:

- First - to increase the share of general education to $80 \%$ and limit the share of vocational education to $20 \%$ of upper secondary school sector;

- Second - to increase gross enrolment index fivefold, to 65\%, by 2010" (Kabaj, 2012, p. 25).

The main premise behind this concept was such that vocational schools were not needed.

This concept was consistently put into practice. As part of the system, students of general and technical upper secondary schools could complete their studies by taking secondary school leaving examination (matura), while students of basic vocational schools could take the matura exam after the completion of a two-year supplementary general upper secondary school or a threeyear supplementary technical upper secondary school.

In 2004, as a continuation of the 1999 reform, an external state examination staged to confirm vocational qualifications was introduced.

"With regard to vocational education and training, external examination will be taken upon the completion of:

- a two-year vocational school - a vocational qualification exam,

- post-secondary vocational school - various forms of validating vocational qualifications.

These examinations will be organised by the Central Examination Board and regional boards appointed by the Minister Edukacji Narodowej [Minister of National Education] in Poland" (Kwiatkowski \& Jeruszka, 2000, p. 50). 
The above issues were governed by the Decree by the Minister of National Education and Sport of 8 May 2004 on the classification of vocational education and training occupations (MEN, 2004).

"In the school year 2009/2010 in Poland there were:

- 1,411 basic vocational schools (excluding special needs schools) providing education to 204,974 students;

- 3,173 technical upper secondary schools, supplementary technical upper secondary schools and general artistic upper secondary schools (ogólnokształcaca szkoła artystyczna) providing education to 612,500 students (including 1907 technical upper secondary schools attended by 517,124 students and 89 supplementary technical upper secondary schools attended by 3375 students);

- 245 public post-secondary schools (szkoła policealna) attended by 33,300 students" (Goźlińska \& Kruszewski, 2013, p. 147).

Within the education system reform introduced on the basis of the act of 19 August 2011, law amending the law on the system of education and certain other acts (Ustawa o zmianie ustawy o systemie oświaty oraz niektórych innych ustaw, 2011), as on 1 September 2014, three-year specialised general upper secondary schools (liceum profilowane), two-year supplementary general upper secondary schools (uzupetniające liceum ogólnoksztatcace) and three-year supplementary technical upper secondary schools (technikum uzupetniajace) were closed down.

However, research results show that:

“(...) contrary to popular opinion, after a sharp decline in interest in vocational schools in the first years of the new century, starting from 2005 there has been a slow, but steady increase in the interest on the part of students in basic vocational schools and technical upper secondary schools. This level of interest in vocational schools can be linked to a sustained demand for workers holding specific vocational qualifications both in the domestic labour market and in the gradually expanding labour market of the European Union. Although in the school year 2009/2010 nearly $9,000(8,780)$ fewer students were admitted to the first year of technical upper secondary schools than in the previous years, and 8,000 $(7,726)$ less students than in the previous year were admitted to the first year of basic vocational schools, the overall percentage of students attending vocational schools as compared to those attending general upper secondary schools in the school year 2009/2010 as compared to the two preceding years did not change. It can therefore be concluded 
that the slightly smaller number of students admitted to technical upper secondary and vocational schools is a consequence of the general demographic trend in the group aged 16-18” (Goźlińska \& Kruszewski, 2013, p. 147).

On 1 September 2017 Polish Ministry of National Education introduced another reform of the education system. One of the assumptions of changes implemented in the system of education was the reform of vocational education and training. Pursuant to Regulations introducing the law on school education (Ustawa przepisy wprowadzające ustawę Prawo oświatowe, 2016) article 162 (1) of the act of 14 December 2016 as on 1 September 2017 the previous basic vocational schools (zasadnicza szkoła zawodowa) were transformed into threeyear stage I sectoral vocational schools (branżowa szkoła I stopnia). Ultimately, the existing 3-year basic vocational schools will be replaced by stage I and stage II sectoral vocational schools. In 2020, the first graduates will complete education at stage I sectoral vocational schools. In the same year, the first admissions to stage II sectoral vocational schools will take place, which will allow for the permeability of vocational education and training as part of the school education system. As a result, graduates of those schools will be awarded certificates confirming their vocational qualifications in occupations taught at the level of technical upper secondary school and a secondary school leaving certificate (świadectwo dojrzałości or matura) opening its holders the doors to higher education.

At the same time, adult learners can continue their education at adult education schools, attend vocational qualification courses or confirm their level of education and vocational qualifications by registering for external examinations.

The assumptions of the education system reform of 2017 give hope for the reactivation of vocational education and training. Undoubtedly, this is a process that concerns not only the very structure of the vocational education and training system, but also relevant study plans and curricula, as well as adequate teaching staff, including practitioners. Changing the way of thinking of parents and students themselves and making them aware of the importance of vocational education and training not only for the country's economy, but also for themselves, plays a significant role in the process. To many young people, vocational education and training is the path leading to professional fulfilment and personal satisfaction. The involvement of employers in vocational education and training, including their participation in the development of curricula and providing opportunities to students to gain practical experience in real-life 
working conditions strongly influence the comprehensive character of implemented changes. The success of the vocational education and training reform will not be determined by the new school structure, but by the social aspects mentioned above and by economic aspects indispensable for genuine activation of entrepreneurs.

\section{Curricular changes in vocational education and training in the years 1999-2017}

The main objective of modern vocational schools is to prepare students for the entry on the labour market. This requires, among other things, responsible development of curricula, which involves employers in the education process. Meanwhile,

“(...) surveys conducted among employers indicated that curricula are often criticised by them for focusing too much on theory, and not keeping up with modern technologies and solutions. What is more, employer involvement in the development of curricula is not a popular form of cooperation with schools. Among companies which cooperate with vocational schools, less than one in five was involved in the development of curriculum" (Goźlińska \& Kruszewski, 2013, p. 30).

Cooperation with employers on the development of curriculum is one of the most important elements shaping effective education. According to K. Denek:

"The effectiveness of vocational school education is expressed by a set of positive features of the didactic and educational process, meaningful and optimal actions, which are at the same time socially and economically justified, and which yield the best results in terms of learning outcomes (including: knowledge, skills, habits, interests and cognitive abilities, motives, convictions and being used to lifelong learning)" (Denek, 1992, p. 41).

The author, continued this thought saying that: "The effects of educational training have their rank in societies that treat education as an important factor for economic growth and are oriented towards the labour market" (Denek, 2013, p. 15).

It is worth quoting the opinion of Urszula Jeruszka, who, referring to the effectiveness of vocational education and training, stated that: 
"You can talk about the effectiveness of vocational education when it forms one of essential elements of general education and is consistent with real economic needs and the requirements of the (local, regional, national, European) labour market. I believe that the effectiveness of vocational education is a measure of its learning outcomes' compliance with adopted objectives of vocational education, i.e. a measure of the degree to which objectives have been achieved. At the same time it forms the assessment of the scope and level of these objectives, with taking them into account when formulating work requirements, with minimum input of resources in the process of achieving them, taking into account the influence of the time factor. The effectiveness of vocational education is a response of VET system to the demand of the labour market for specific occupations, which are taught within the school system" (Jeruszka, 2000, p. 26).

After the reform of 1999, which regulated vocational education and despite leaving it within the structure of school education system, in 2011 significant changes in legal regulations were observed. The Ministry of National Education made an attempt to adapt curricula to the requirements of the labour market by developing them based on learning outcomes, which were divided into knowledge, skills and social competencies are defined as "mastery in using relevant information when performing specific tasks" (Okoń, 2007, p. 439). However, competency is defined as:

"the scope of powers and authority to act, make decisions and opinions in a specific area granted on the basis of relevant qualifications. You are competent, if you have the authority to act and possess relevant qualifications. The term competency is also used when qualifications are accompanied by the accountability for the way they are used by a qualified, and thus competent person" (Nowacki, 2004, p. 100).

Janina Elżbieta Karney expanded the concept of competency by explaining that it also includes "dimensions of personality of an employee, such as, for example, sense of responsibility, self-control, discretion, criticism, etc." (Karney, 2007, p. 32).

The work on core curriculum included the assumptions of the Bologna Process (2005) concerning the development of a system allowing for comparing the outcomes and qualifications of lifelong learners. For this purpose, European and National Qualifications Frameworks were developed. Poland was obliged to implement them in accordance with the Communique of the Conference of European Ministers responsible for Higher Education, that took place in Bergen on 19-20 May 2005 and the Recommendation of the European Parliament and 
of the Council of 23 April 2008 on the establishment of the European Qualifications Framework for lifelong learning (Council of the EU, 2008).

Pursuant to the Act of 19 August 2011 (Ustawa o zmianie ustawy o systemie oświaty oraz niektórych innych ustaw, 2011) the Ministry of National Education implemented a thorough reform of the model of vocational education at secondary school level. A new core curriculum for vocational education in occupations was implemented, the classification of school occupations was modified, and the structure of upper secondary school education was changed. The main objective of the changes was to increase the effectiveness and efficiency of vocational education and training system and to adapt it to the labour market requirements, among other things, by:

- Modifying the classification of vocational education occupations with taking into account the division of occupations into qualifications separately validated in the education process.

- Modifying new core curriculum for vocational education in occupations.

- Adapting the structure of education to the new model of vocational and continuing education, including:

1. standardising educational cycle of basic vocational schools;

2. consolidating vocational and continuing education at vocational and continuing education centres;

3. creating opportunities for adult learners to obtain vocational qualifications by participating in qualification courses provided by schools, education providers and training companies;

- Standardising the system of examinations taken to confirm vocational qualifications and introducing the possibility to register for examinations after completing non-formal (courses) and informal learning.

- Including schools providing vocational education in the system of continuing education.

- Phasing out (by September 2014) specialised general upper secondary schools [liceum profilowane].

The changes concerning the modification of vocational education and training entered into force on 1 September 2012. On the basis Decree by the Minister of National Education of 23 December 2011 (MEN, 2012d), education in 200 occupations was introduced and 252 qualifications were identified within occupations, and individual occupations were assigned to eight areas of study.

The new core curriculum for all occupations was introduced with the Decree by the Minister of National Education of 7 February 2012 (MEN, 2012a) and entered into force on 1 September 2012. 
Vocational education was provided on the basis of two core curricula: i.e. general education and vocational education in occupations core curriculum. The structure of the new core curriculum differed from the previous ones. The new core curriculum was developed on the basis of learning outcomes divided into knowledge, skills and social competency. This model corresponded to the concept developed in the European Union as part of the Bologna Process.

The core curriculum was divided into three parts:

- Part 1, which describes general objectives and tasks of vocational education and includes a table containing a list of qualifications and their links with occupations and learning outcomes;

- Part 2, which includes learning outcomes common for all occupations, learning outcomes common for occupations within an area of study forming the basis for education in an occupation or a group of occupations and learning outcomes relevant for qualifications identified in occupations;

- Part 3, which contains a description of education in individual occupations, which includes: names and digital symbols of occupations, according to the classification of occupations in vocational education and training, objectives of vocational education and training in occupations, names of qualifications identified in occupations, conditions for providing education and training in occupations, minimum number of hours of vocational education and training and the possibility of being awarded additional qualifications in occupations within an area of study defined in the classification of occupations in vocational education and training.

The new core curriculum is consistent with the Polish Qualifications Framework (with the National Qualifications Framework as part of the previous reform). "In our research into vocational qualification standards we assumed that the elements of the structure of standards include information, skills and psychophysical characteristics referring to the set of tasks assigned to a given occupation" (Kwiatkowski \& Jeruszka, 2000, p. 52).

Occupations included in the classification of occupations in vocational education and training are the ones including one, two and three qualifications. Seven occupations are classified in the area of artistic education, for which no qualifications have been distinguished.

Each qualification is confirmed by means of a separate external vocational qualification examination. The examinations can be taken by vocational school students, learners who completed qualification courses or who learned on their own (on the job). 
Being awarded all qualifications required for a given occupation entitles to the award of a certificate.

We have assumed that vocational qualification standards include five levels, which are described in a manner similar to British National Vocational Qualification (NVQ) standards:

"Level 1. Qualifications necessary to perform simple, routine tasks carried out under the supervision of a superior, constituting the basis for further, more specialised activities.

Level 2. Qualifications necessary to perform tasks in typical situations. Some tasks may be more complex and may require taking independent action involving individual responsibility, and may require teamwork skills.

Level 3. Qualifications necessary to perform complex tasks, both in typical and problem conditions. Tasks are characterised by a diversity of activities performed and require independence and responsibility. They may also include the ability to manage the work of other people.

Level 4. Qualifications necessary to carry out a wide variety of complex technical, organisational or specialist tasks in a given area of professional activity. Tasks require taking personal responsibility and independence and the ability to lead a team of employees.

Level 5. Qualifications necessary to perform complex tasks, often in problem situations, requiring taking decisions of strategic importance for the organisation. These tasks involve taking full responsibility for the work and development of others, and require the ability to diagnose, analyse, forecast, plan and implement new ideas into business practice.

Each of these levels can be associated with the four basic types of qualifications, which include:

- Supra-vocational qualifications - basic requirements that are to be met when performing any work, both professional and non-professional (e.g. social work or domestic tasks) and are expressed by positive attitudes and positive physical condition and by mastering basic practical and mental skills. These qualifications are not targeted at any particular occupation and do not authorise their holder to do the job.

- General vocational qualifications are targeted at a certain occupational area, which usually covers a group of occupations.

- Basic vocational qualifications are targeted at a specific occupation and include the main skills needed to practice it successfully.

- Specialist qualifications are additional skills specific to a given occupation, which should be equated with vocational specialisations or scopes of work" (Kwiatkowski \& Jeruszka, 2000, p. 53). 
Two decrees by the Minister of National Education were important instruments that supplemented the new model of vocational education. These were:

- Decree by the Minister of National Education of 24 February 2012 (MEN, 2012b),

- Decree by the Minister of National Education of 14 September 2012 (MEN, 2012c).

In accordance with the above instruments, the vocational qualification examinations were staged throughout the school year at dates set by the director of a district examination board, in agreement with the director of the central examination board.

Learners who completed vocational courses leading to the award of a qualification and persons who wanted to have their vocational qualifications validated could enter for external examinations in order to have their qualifications in a given occupation attested. Successfully passed examination authorised an adult learner to be awarded a certificate attesting that its holder possesses a given qualification.

Attestation of all qualifications identified in a given occupation and obtaining an appropriate level of education was a precondition for the award of a certificate attesting vocational qualifications and a certificate supplement.

An important aspect of the process of training students for the labour market is to take into account the international character of the labour market that contemporary graduates of vocational schools gain access to. After Poland's accession to the European Union on 1 May 2004, EU member states have gradually opened their markets for workers from our country. These workers represented various occupations. They were nurses, plumbers, roofers and waiters. Many of them adopted quickly to the new conditions in Germany, Great Britain and Sweden, to mention a few countries.

As a result, the perception of vocational education has been changing. Vocational education is defined as "training offered to people who completed relevant general education to do specific jobs, provided by lower- and uppersecondary vocational schools, higher education institutions, courses and workplaces" (Okoń, 2007, p. 207). The aim of vocational education is 1) to teach knowledge in these specific fields which are common to all occupations covered by a given vocational education programme, 2) to teach typical methods, means and forms of professional activity, 3) to develop special abilities and interests necessary to do a given job, 4) to make learners accustomed to continuous improvement of qualifications (Okoń 1992, p. 104). 
As an outcome of vocational education, qualifications to do a specific job are awarded. Tadeusz W. Nowacki defines the term qualification as:

"mastering by a given person or a group of persons of one or more mental and practical skills systems based on corresponding theoretical and practical knowledge systems suitable for effective solution of various, yet specific classes of vocational tasks supported by appropriate personality systems" (1977, p. 58).

The concept of qualification is closely related to competency, the development of which

“(...) can be seen in terms of progress expressed by the broadening of knowledge and expansions of skills and social competency. In this context, knowledge, skills and social competency are the outcome of on-the-job learning, which corresponds to the recommendations of the European Union concerning the establishment of European Qualifications Framework" (Sławiński, 2014, p. 57).

Qualifications and competencies are subject to continuous improvement as part of professional development process. According to S.M. Kwiatkowski, the notion of professional development can be replaced by the notion of a career path. This notion is characterised by the systems of knowledge, skills and social competencies, which are elements of vocational competencies that describe three stages:

"development - increase in knowledge, skills and social competency;

- stagnation - lack of increase in knowledge, skills and social competency;

- regress - decline in knowledge, skills and social competency" (Kwiatkowski, 2017a, p. 150).

Moreover, the author while characterizing professional development in the work process emphasizes the role of internal conditions dependent on the employee and external conditions dependent on the characteristics of the enterprise.

Professional development is conditioned by the environment in which the employee operates, the organisational culture of a given company, as well as the awareness of the management of the functions performed by the workplace. According to S.M. Kwiatkowski "Enterprises serve various, interrelated functions. These include: production, service, social, didactic and educational functions" 
(2017b, p. 157). Taking into account the topic of this article, the didactic function deserves special attention, as:

"It combines providing employees with conditions for systematic education, in-service training and professional development. On-the-job training requires that an enterprise creates a work organisation system, which enables the performance of professional tasks as part of flexible forms of employment - taking into account the need to participate in classes at school or higher education institution" (Kwiatkowski, 2017b, p. 158).

At the same time, he believes that the role of the employer in the process of in-service training consists in "choosing the most effective forms of training and providing appropriate organisational and financial conditions (replacements, covering the costs, providing a selected form of in-service training)" (Kwiatkowski, 2017b, p. 158).

Moreover, professional development of staff should be "preceded by the development of an individual professional development plan and programme, which take into account the abilities and aspirations of a given staff member" (Kwiatkowski, 2017b, p. 158).

Another reform of vocational education was introduced with the Act of 14 December 2016 Law on school education (Ustawa Prawo oświatowe, 2016) and the Act of 14 December 2016 Regulations introducing the law on school education (Ustawa Przepisy w prowadzające ustawę Prawo oświatowe, 2016). These legal instruments introduced sectoral vocational school education and new types of schools:

- three-year stage I sectoral vocational school (branżowa szkoła I stopnia);

- two-year stage II sectoral vocational school (branżowa szkoła II stopnia);

- five-year secondary technical school.

The curricular contents for the above mentioned schools were specified in the Decree by the Minister of National Education of 14 February 2017 (MEN, 2017).

The assumptions for the functioning of sectoral vocational schools are specified in the Decree by the Minister of National Education of 15 February 2019 (MEN, 2019). Graduates of schools providing vocational education should have full vocational qualifications and be prepared to obtain indispensable professional qualifications.

Cooperation of employers with vocational schools is one of the most important elements affecting the quality of education. According to Kwiatkowski, the educational function of enterprises at the local level consists in: 
- "providing content-related assistance in the design of new vocational training programmes;

- cooperation on the development of learning objectives in the form of competency and qualification systems;

- providing advice on the development of alternative educational contents;

- participation in the development of education plans, with a particular focus on student activation methods;

- organising practical training and work placements in enterprises, site visits for students, consultations for students and training for teachers (making training stations available, preparation of documentation, appointment of instructors and mentors);

- co-organising competitions to integrate subject related knowledge and skills;

- funding scholarships for outstanding students;

- organising examinations to attest vocational qualifications" (Kwiatkowski, 2017b, p. 163).

This view is reflected in the guidelines for the Decree by the Minister of National Education of 15 February 2019 (MEN, 2019) according to which:

"Close cooperation between schools providing vocational education and employers is an important element of modern education and responds to the needs of contemporary economy. The school providing vocational education should implement training on the basis of cooperation with employers, and practical training should take place as much as possible in actual working environment, at employers or individual farms, as well as at vocational training centres, school workshops, school laboratories and continuing education providers" (MEN, 2019).

As a principle, stage I sectoral vocational schools offer education leading to the award of one qualification. Graduates of these schools - having passed an examination to attest the qualification - are awarded certificates attesting their vocational qualification, and completion of basic sectoral vocational education. At stage II sectoral vocational schools, students are trained in occupations, in which they can continue education at secondary technical schools. Having graduated from stage II sectoral vocational school and having passed the examination to attest holding the second qualification, graduates will complete secondary sectoral vocational education and will be awarded a technician certificate. It is worth noting that graduates of stage II sectoral vocational schools will be able to enter for secondary school leaving examination (matura), and having 
been awarded matura certificate they will be able to continue their education at higher education institutions. Graduates of stage I sectoral vocational schools who will not choose to continue training in their occupations at stage II sectoral vocational schools will be able to take up employment or continue their education in the second year of a general secondary school for adult learners and opt for vocational qualification courses. In order to pass the examination confirming qualifications in the occupation, students need to obtain at least $50 \%$ of the total number of points for each component of the written part of the examination and at least $75 \%$ of the total number of points for each component of the practical part of the examination.

Career guidance plays an important role in the process of preparation process for choosing an occupation.

"The decision on the career choice requires:

- detailed information about educational offer of local vocational schools,

- diagnosis (self-diagnosis) of interests and abilities, as well as of health and the system of values,

- analysis of vocational competency standards and opportunities for continuing education and in-service training in the occupation(s) concerned,

- comparing the results of the diagnosis (self-diagnosis) with employer requirements expressed in vocational competency standards related to the occupation" (Kwiatkowski, 2012, pp. 163-172).

In line with the principles of the 2017 reform, career guidance was introduced at all stages of education, starting from primary school. It is noteworthy that the career guidance classes are also included in the study plans for stage I and stage II sectoral vocational schools. Such a solution allows students of these schools to verify their decisions concerning their education and career choices.

\section{Summary}

From 1999 to 2017 profound changes were observed in vocational education and training in Poland. Their character and scope varied. Their results also differed, which was most evident in the VET sector. According to the report entitled Efektywne szkolnictwo zawodowe jako kluczowy element nowoczesnej gospodarki [Effective Vocational Education and Training as a Key Element of Modern Economy] published by the Warsaw Enterprise Institute, in the 
2014/2015 school year 3,954 basic vocational schools and secondary technical schools operated in Poland. This means that since 2008 their number decreased by nearly $20 \%$. Since 2000 , the decline in the number of these schools reached $50 \%$. According to the latest data from the Central Statistical Office (GUS), in the school year 2016/2017 there were even fewer vocational schools and secondary technical schools, totalling roughly 3,500 .

Changes in vocational education and training were also visible in the labour market. They were mainly manifested by the shortages of qualified professionals. This is why the reform of the education system, including vocational education and training sector was introduced in 2017 in response to the above situation, which gives hope for a positive change. However, this is a very complex problem, which requires commitment on the part of education and business sector, as well as the involvement of parents of primary school pupils whose children may become future candidates for stage I sectoral vocational schools. Moreover, building a positive image of vocational education and training in society, both at the level of secondary schools and sectoral vocational schools offering training in blue collar jobs, which are in high demand in the labour market, is an important factor here. Raising awareness of the role, importance and the need to respect each occupation is an urgent social challenge.

\section{References}

Council of the EU (2008). Recommendation of the European Parliament and of the Council of 23 April 2008 on the Establishment of the European Qualifications Framework for lifelong learning (2008/C 111/01). Retrieved 16th May 2020 from https://eur-lex.europa.eu/legal-content/ .

Denek, K. (1992). Nowe paradygmaty pomiaru efektywności w szkolnictwie zawodowym [New Paradigms for Measuring Performance in Vocational Education]. Pedagogika Pracy, (20/2), 41-50.

Denek, K. (2013). Rola edukacji w tworzeniu kapitału ludzkiego [The Role of Education in Human Capital Formation]. In: U. Szuścik (Ed.), Teoria i praktyka pedagogiczna w refleksji naukowej i praktycznej [Theory and Pedagogical Practice in Scientific and Practical Reflection], (pp. 11-37). Katowice: Cieszyński Almanach Pedagogiczny, Wydawnictwo Uniwersytetu Śląskiego.

Fundacja Warsaw Enterprise Institute WEI (2016). Efektywne szkolnictwo zawodowe jako kluczowy element nowoczesnej gospodarki. Raport. [Effective Vocational Education and Training as a Key Element of Modern Economy. Report]. Warszawa: Fundacja 
Warsaw Enterprise Institute). Retrieved 10 May 2020 from http:/www.cwrkdiz.kalisz. pl/images/RAPORT_efektywne-szkolnictwo-zawodowe-2016-WEI.pdf.

Goźlińska, E., \& Kruszewski, A. (2013). Stan szkolnictwa zawodowego w Polsce [Condition of Vocational Education in Poland]. Warszawa: Krajowy Ośrodek Wspierania Edukacji Zawodowej i Ustawicznej.

GUS (2017). Oświata i wychowanie w roku szkolnym 2016/2017. [Education in 2016/2017 School Year]. Warszawa: Central Statistical Office (GUS). Retrieved 10 May 2020 from https://stat.gov.pl/obszary-tematyczne/edukacja/edukacja/oswiata-i-wychowanie-w-roku-szkolnym-20162017,1,12.html\#.

Jeruszka, U. (2000). Efektywność kształcenia zawodowego. Kształcenie zawodowe a rynek pracy [Effectiveness of Vocational Training. Vocational Training and the Labour Market]. Warszawa: Instytut Pracy i Spraw Socjalnych.

Kabaj, M. (2012). Wpływ systemów ksztatcenia zawodowego na zatrudnienie i bezrobocie młodzieży. Projekt programu wdrożenia dualnego systemu ksztatcenia zawodowego $w$ Polsce [Impact of Vocational Education Systems on Youth Employability and Unemployment. Draft Programme for the Implementation of a Dual Vocational Training System in Poland]. Warszawa: Instytut Pracy i Spraw Socjalnych.

Karney, J.E. (2007). Psychopedagogika pracy: wybrane zagadnienia z psychologii i pedagogiki pracy [Psychopedagogy of Work: Selected Issues in Labour Psychology and Pedagogy]. Warszawa: Wydawnictwo Akademickie Żak.

Kwiatkowski, S.M. (1993). New Relationships Between the Labour Market and the Education System in Poland. Warszawa: OECD.

Kwiatkowski, S.M. (2002). Edukacja zawodowa wobec zmian społeczno-gospodarczych [Vocational Education and Socio-Economic Changes]. Pedagogika Pracy, 40 (02), 46-56

Kwiatkowski, S.M. (2017a). Wyznaczniki drogi zawodowej [Determinants of Carrer Path]. Edukacja Ustawiczna Dorostych, 4(99), 148-156.

Kwiatkowski, S.M. (2017b). Edukacyjne funkcje współczesnych przedsiębiorstw [Educational Functions of Contemporary Enterprises]. Edukacja Ustawiczna Dorostych, 4(99), $157-166$.

Kwiatkowski, S.M. (2012). Standardy kwalifikacji i kompetencji zawodowych [Standards of Vocational Qualifications and Competencies]. In: S.M. Kwiatkowski (Ed.), Zawód i praca. W świecie urynkowienia i konkurencji globalnej [Occupation and Work in the Era of Economic Liberalisation and Global Competition]. Studia Pedagogiczne, LXV, $163-173$.

MEN [Ministry of National Education] (2004). Rozporządzenie Ministra Edukacji Narodowej i Sportu z dnia 8 maja 2004 w sprawie klasyfikacji zawodów szkolnictwa zawodo- 
wego (Dz. U. 2004, poz. 1195) [Decree by the Minister of National Education and Sport of May 8, 2004 on the classification of vocational education and training occupations, OJ 2004, item 1195]. Retrieved 12 December 2018 from http://isap.sejm.gov.pl/.

MEN [Ministry of National Education] (2012a). Rozporządzenie Ministra Edukacji Narodowej z dnia 7 lutego 2012 r. w sprawie podstawy programowej kształcenia w zawodach (Dz.U. 2012, poz. 184) [Decree by the Minister of National Education of February 7, 2012, on core curriculum for vocational education in occupations, OJ 2012, item 184]. Retrieved 15 December 2019 from http://isap.sejm.gov.pl/.

MEN [Ministry of National Education] (2012b). Rozporządzenie Ministra Edukacji Narodowej z dnia 24 lutego 2012 r. w sprawie warunków i sposobu oceniania, klasyfikowania i promowania uczniów i słuchaczy oraz przeprowadzania sprawdzianów i egzaminów w szkołach publicznych (Dz.U. 2012, poz. 262) [Decree by the Minister of National Education of February 24, 2012, on the conditions and method of assessing, classifying and promoting students and learners and on administering tests and examinations in public schools, OJ. 2012, item 262]. Retrieved 15 December 2019 from http://isap. sejm.gov.pl/.

MEN [Ministry of National Education] (2012c). Rozporządzenie Ministra Edukacji Narodowej z dnia 14 września 2012 r. w sprawie egzaminu czeladniczego, egzaminu mistrzowskiego oraz egzaminu sprawdzającego, przeprowadzanych przez komisje egzaminacyjne izb rzemieślniczych|(Dz.U. 2012, poz. 1117) [Decree by the Minister of National Education of September 14, 2012, on the apprentice examination, master craftsman examination and verification examination staged by examination boards at chambers of crafts, OJ 2012, item 1117]. Retrieved 10 December 2019 from http://isap.sejm.gov.pl/.

MEN [Ministry of National Education] (2012d). Rozporządzenie Ministra Edukacji Narodowej z dnia 23 grudnia 2011 r. w sprawie klasyfikacji zawodów szkolnictwa zawodowego (Dz. U. 2012, poz. 7) [Decree by the Minister of National Education of December 23,2011 , on the classification of occupations in vocational education and training, OJ 2012, item 7]. Retrieved 30 December 2019 from http://isap.sejm.gov.pl/.

MEN [Ministry of National Education] (2017). Rozporządzenie Ministra Edukacji Narodowej z dnia 14 lutego 2017 r. w sprawie podstawy programowej wychowania przedszkolnego oraz podstawy programowej szkolnictwa ogólnego dla szkoły podstawowej, w tym dla uczniów z niepełnosprawnością intelektualną w stopniu umiarkowanym lub znacznym, kształcenia ogólnego dla branżowej szkoły I stopnia, kształcenia ogólnego dla szkoły specjalnej przysposabiającej do pracy oraz kształcenia ogólnego dla szkoły policealnej (Dz. U. 2017, poz. 356) [Decree by the Minister of National Education of February 14, 2017, on core curriculum for preschool education and core curriculum for general education at primary schools, including core curriculum for students with moderate or significant intellectual disability, for general education at stage I sectoral vo- 
cational schools, for general education at special needs schools offering work training and for general education at post-secondary schools, OJ 2017, item 356]. Retrieved 15 December 2019 from http://isap.sejm.gov.pl/.

MEN [Ministry of National Education] (2019). Rozporządzenie Ministra Edukacji Narodowej z dnia 15 lutego 2019 r. w sprawie ogólnych celów i zadań kształcenia w zawodach szkolnictwa branżowego oraz klasyfikacji zawodów szkolnictwa branżowego (Dz.U. 2019, poz. 316). [Decree by the Minister of National Education of February 15, 2019, on general objectives and tasks of training in vocational education occupations and the classification of sectoral vocational education occupations, OJ 2019, item 316]. Retrieved 15 December 2019 from http://isap.sejm.gov.pl/.

Nowacki, T. (1977). Podstawy dydaktyki zawodowej [Introduction to Vocational Training]. Warszawa: Państwowe Wydawnictwo Naukowe.

Nowacki, T.W. (1999). Zawodoznawstwo [Knowledge on Occupations and Jobs]. Radom: ITeE.

Nowacki, T.W. (2004). Leksykon pedagogiki pracy [Lexicon of Labour Pedagogy]. Radom: Instytut Technologii Eksploatacji.

Okoń, W. (2007), Nowy Stownik Pedagogiczny [New Dictionary of Pedagogical Terms]. Warszawa: Wydawnictwo Akademickie Żak.

Okoń, W. (1992). Stownik Pedagogiczny [Dictionary of Pedagogical Terms]. Warszawa: Wydawnictwo Naukowe PWN.

Sławiński, S. (Ed.), (2014). Słownik podstawowych terminów dotyczacych krajowego systemu kwalifikacji [Glossary of Key Terms Related to National Qualifications System]. Warszawa: Wydawnictwo Instytutu Badań Edukacyjnych.

Ustawa o zmianie ustawy o systemie oświaty (1998). Ustawa z dnia 25 lipca 1998 r. o zmianie ustawy o systemie oświaty, Dz.U. 1998, poz. 759 ze zm. [Act of 19 August 2011, the law amending the law on the system of education and certain other acts, OJ 1998, item 759 with changes].

The Bologna Process (2005). The European Higher Education Area: Achieving the Goals. Communique of the Conference of European Ministers responsible for Higher Education, Bergen, 19-20 May 2005. Retrieved 16th May 2020 from: http://www.ehea.info/ page-ministerial-conference-bergen-2005

Ustawa o zmianie ustawy o systemie oświaty oraz niektórych innych ustaw (2011). Ustawa z dnia 19 sierpnia 2011 r. o zmianie ustawy o systemie oświaty oraz niektórych innych ustaw, Dz.U. 2011, poz. 1206 ze zm. [Act of August 19, 2011, amending the act on the system of education and certain other acts, OJ 2011, item 1206 with changes]. 
Ustawa Prawo oświatowe (2016). Ustawa z dnia 14 grudnia 2016 r. Prawo oświatowe, Dz.U. 2017, poz. 59 ze zm. [Act of December 14, 2016, Law on school education, OJ 2017, item 59 with changes].

Ustawa przepisy wprowadzające ustawę Prawo oświatowe (2016). Ustawa z dnia 14 grudnia 2016 r. Przepisy wprowadzające ustawę Prawo oświatowe, Dz.U. 2017, poz. 60 ze zm. [Act of December 14, 2016, Regulations introducing the law on school education, OJ 2017, item 60 with changes]. 